\title{
A Study on the Syntactic and Semantic Meaning of the Epistemic Modal Adverb "Meizhunr"
}

\author{
Chengnan Jia \\ School of Humanities \\ Zhejiang University \\ Hangzhou, China
}

\begin{abstract}
Meizhunr" is mainly used as an adverbial with flexible syntactic position. It belongs to the outside-proposition element. And it has the syntactic function of epistemic modal adverb. "Meizhunr" can be in front of the subject. And it has the highest frequency of co-occurrence with the epistemic modal verbs. When the modal verbs and "Meizhunr" are in the same sentence, the basic word order is "Meizhunr" > "Modal verbs". When the adverbs and "Meizhunr" are in the same sentence, the position is more flexible. "Meizhunr" has semantic features such as [+ speculative], [+ uncertainty], [+ irrealis], which express the speaker's subjective speculative about the content of expression.
\end{abstract}

Keywords-"Meizhunr"; epistemic modal adverb; syntax; semantic

\section{INTRODUCTION}

It is generally accepted that "Meizhunr" is an auxiliary verb (i.e. modal verb). It means "uncertainty, perhaps". 1 Some studies also suggest that "Meizhunr" is an epistemic modal adverb showing uncertain conjecture 2 or deduction (Xu Jingning, 2005: 292). Others regard it as a "fixed structure" (Wu Chunlan, 2009: 26). "Meizhunr" shows that the speaker has a positive subjective tendency to predict uncertain events (Wang Qiuping, 2015: 27). "Meizhunr" can act as an adverbial or predicate (Wu Chunlan, 2009: 28). By searching the CCL Modern Chinese Corpus of Peking University, we find that "Meizhunr" is mainly used as an

"Modern Chinese Dictionary (Seventh Edition)" considers "Meizhunr" to be auxiliary verbs. It means "not necessarily". It is possible ("Meizhunr") to come true the thing. The "Modern Chinese Canonical Dictionary" considers "Meizhunr" to be spoken language and an auxiliary verb, meaning "maybe, there is a possibility". He will not come back, maybe ("Meizhunr"). It is also an adjective, meaning "unreliable". In the "Dictionary of Common Use of Chinese Dialects", "Meizhunr" belongs to northern dialects, meaning "indefinite". "Eight Hundred Words of Chinese Modern", "Chinese Dictionary of Modern Chinese Function Words," and "Note of Modern Chinese Function Words" have not included "Meizhunr ".

Luo Yaohua, Liu Yun (2008:44) think that speculative tone adverbs belong to the category of epistemic modaI adverbs. "It is a subjective expression of the speaker's uncertainty about things (including people and events) and "Meizhunr" belongs to this kind of epistemic modal adverbs. adverbial. And its syntactic and semantic features are similar to those of the epistemic modal adverb3.

\section{ThE SYNTACTIC FEATURES OF "MEIZHUNR"}

By analyzing the fact that "Meizhunr" is used as a syntactic component in the sentence, we find that it is mainly used as an adverbial, which can co-occur with adverbs, modal verbs, and combinations of adverbs and modal verbs.

\section{A. As an Adverbial}

"Meizhunr" is mainly used as an adverbial and can be used to decorate the whole sentence. From the distribution of adverbials, "Meizhunr" is mainly used in the middle of sentence. When it is used at the beginning of a sentence, it modifies the whole sentence before the subject. For example:

（1）我的妈呀，什么古董都存着! 这没准儿还是你小时候用过的 呢。Oh my God, all antiques are kept! Maybe ("Meizhunr") it's something you used when you were a kid. (Chen Jiangong, Zhao Danian. "Huangchenggen")

(2) 当初要不是李力看她天生是个打不死的小强，收了她，没准 她至今还在傻呵呵地瞎混。If it hadn't been for Li Li's view that she was born to be an unbreakable Xiaoqiang, she would have been taken away. And perhaps ("Meizhunr") she was still foolishly fooling around. (Li Ke. "A Story of Lala's Promotion")

（3）假如你不愿意见我的话，我可以专来找她; 也许约她出去走 一走, 没准! If you don't want to see me, I can come to see

Shi Jinsheng (2003) believes that the knowledge-based adverbs (awareness of modal adverbs) of the propositions on the success and validity of the proposition are divided into affirmative and inferential categories, in which the inference indicates that "the truth of the proposition is to be inferred. Estimation is divided into two categories: predictive (or contingent) and deterministic (necessary)." Xu Jingning (2005: 285), "According to Zhang Yisheng and Shi Jinsheng's research, the syntactic features of modal adverbs are summarized as predicate (high predicate), flexibility (which can be located in the beginning, middle and end of sentence), and dynamic (only in the predicate clause and the complement clause). And it cannot be in the attributive clause and the adverbial clause. Many modal adverbs can be found in the object clause when the sentence predicate verb is a verb indicating speech, psychology or cognitive meaning. The object clause is dynamic, preposition (and other adverbs application, generally located in the front), usually located at the front of the 'shi'." However, Xu thinks "Meizhunr" cannot be located in the beginning of the sentence. It can be just in the middle of the sentence. 
her. I would ask her to go out for a walk, maybe ("Meizhunr")! (Lao She. "Alliance")

(4) 没准。不一定。几个月一次, 半年一次。 Maybe ("Meizhunr"). Perhaps, it is once a few months or once half a year. (Lu Xin. "The Deadly Sky")

We find that "Meizhunr" can be distributed in the beginning (before the subject) and middle of the sentence as an adverbial. Also, it can be at the end of the sentence or "used alone". The syntactic position is more flexible. Its scope is the whole sentence. And it belongs to the element outside the propositional.

\section{B. Co-occurrence with Adverbs}

Adverbs often appear in the same sentence as "Meizhunr"4. It is mainly after the "Meizhunr". Also, it may be before or after the adverbs. And the position is more flexible.

\section{1) Adverb postposition}

The co-occurrence of "Meizhunr" and the subsequent adverbs can be divided into two types: continuous type and non-continuous type. The continual co-occurrences with "Meizhunr" mainly include adverbs such as "just(jiu), still(hai), also(ye), again(you), being(zheng), truly(zhen), early(zao), again(zai), soon(jiang), much(duo), by coincidence(pengqiao)". And the adverbs forming discontinuous co-occurrence mainly include" just(jiu), still(hai), also(ye), again(you), being(zheng), not(bu), all(dou), just(jin), more(geng), over(guo), against(fan), just(gang), only(pian), also(haishi), exactly(dique), ever(yijing), not yet(shangwei), actually(daoshi), forever(yongyuan), just(jiushi), being(zhengzai), always(zongshi)" etc. For example:

(5) 刚才你说的那些事加起来也不过是半个月的事, 可我和我爸 一起呆了十多年, 要想再找出半个月他怎么对我好的事也一样很容 易, 你要听了那些事没准就会得出结论: 他是天底下最好的父亲一 就看人家给你听的是什么了。The things you said just now are all in only half a month. However, my father and I have been together for more than ten years. And it is as easy to find out some good things he has done to me in half a month. You may ("Meizhunr") conclude that he is the best father in the world - it depends on what he has told you. (Wang Shuo. "I'm your father")

（6）我真不会受刺激, 只会为你高兴, 你就满足一下我的好奇心 吧, 没准我和她还能成为好朋友呢一一求你了。I'm not really excited. And I'm just happy for you. And you just satisfy my curiosity. Maybe ("Meizhunr") she and I can still be good friends - please. (Wang Shuo. "No one cheers")

\section{2) Adverb preposition}

The adverbs that can be placed before "Meizhunr" include "just(ke), just(jiu), also(ye), truly(zhen), much(hen),

Wu Chunlan (2009:30) believes that the adverbs appearing before "Meizhunr" and "not necessarily" include "just(jiu), again(you), only(cai), truly(zhen), still(hai)", etc. The adverbs appearing behind them include "still(hai), again(you), also(ye), truly(zhen), and so on". They can also have adverbs before and after it. again(you), yet(cai), still(hai), all(dou), more(geng), exactly(daoshi)". Sometimes, there will be cases where two adverbs are continuously co-occurred. For example:

(7) 如果不是爱上赛车, 她曾经经营的送餐公司也许会非常成 功, 也没准儿她会成为一个优秀的家庭主妇。Had she not been in love with racing, the delivery company she had run might have been very successful, and perhaps ("Meizhunr") she would have become a good housewife. (Xinhua News Agency, December 2001, news report)

（8）不过倒也没准把话说过头了。However, perhaps ("Meizhunr") it says too much. (Reading vol-074)

3) Adverbs appear before and after "Meizhunr"

There are few adverbs before and after "Meizhunr", for example:

（9）若不同意别人的意见，虽然不至于朝人家扔臭鸡蛋，还真没 准他就能从手下的面包撕下小团, 当场抛向对方。If he don't agree with others, he don't want to throw stinky eggs at them, and he might ("Meizhunr") be able to tear small buns from his bread and throw them at each other on the spot. (Li Ke. "A Story of Lala's Promotion")

\section{Co-occurrence with Modal Verbs}

All types of modal verbs5 can appear after "Meizhunr". And its composition is not continuous. The epistemic modal verbs and deontic modal verbs after "Meizhunr" and its composition can be continuous. According to the corpus, "Meizhunr" appears before the modal verbs, which indicates that "Meizhunr" has a higher syntactic position and a higher degree of subjectivity than the modal verbs.

"Meizhunr" can be combined with the epistemic modal verb such as "can(hui, neng), would(gai), should(dei, yao) ". It would be continuous co-occurrence or non-continuous cooccurrence. The non-continuous co-occurrence occupies a higher proportion. For example:

(10) 要是早先, 瑞宣没准儿会笑上一笑, 说两向俏皮话把丁约翰 打发走。If it had been earlier, Ruixuan might ("Meizhunr") have laughed and sent Ding John away with a couple of witticisms. (Lao She. "Four Generations under One Roof")

(11) 要是契诃夫还活着, 没准真会发生这样的事。If Chekhov were alive, this might ("Meizhunr") happen. (Zhang Jie. "Love, can't be forgotten")

The deontic modal verb such as "want(yao), can(keyi), should(gai, yinggai), " can be followed by "Meizhunr". And they could form discontinuity co-occurrence. For example:

(12) 婚后老婆开始插手财政大权, 理由是单位要盖集资房, 没准 啥时就该交钱了。After marriage, the wife begins to meddle in the financial power. The reason is that the unit wants to build the fund house, perhaps ("Meizhunr") they should pay money. (Web corpus, C000013)

\footnotetext{
Peng Lizhen (2007: 160) classifies modern Chinese modal verbs into three categories: epistemic modal verbs, moral modal verbs, and dynamic modal verbs.
} 
Dynamic modal verbs "may(keyi)" and "can(neng)" can be placed after "Meizhunr". And the discontinuous dynamic modal verbs such as "think(xiang), can(neng), would(yao), could(hui, keyi)" appear after "Meizhunr". For example:

（13）赵忠涛急忙挥手说: “言重了, 言重了。有事你说, 没准儿 能帮上忙呢。”Zhao Zhongtao waved his hand quickly and said, "You are too serious. There's something you can say, maybe ("Meizhunr") I can help." (TV series "The Way of Heaven")

(14) 如果不是在车上, 没准你还想到店里看看, 买点什么。If you're not in the car, you might ("Meizhunr") want to look at the store and buy something. (People's Daily, December, 1993)

Corpus analysis shows that the co-occurrence rate of "Meizhunr" and epistemic modal verbs is the highest, followed by dynamic modal verbs. And the co-occurrence rate of deontic modal verbs is the lowest.

\section{Co-occurrence with Adverbs and Modal Verbs}

"Meizhunr" can co-exist with adverbs and modal verbs. "Meizhunr" often co-occurs with the epistemic modal verbs. The epistemic modal verbs co-occurring with "Meizhunr" include "can(hui, neng), would(gai), must(dei), and want (yao)". These epistemic modal verbs can co-occur with the adverbs such as "just(jiu), still(hai), also(ye), again(you), $\operatorname{not}(b u)$, actually(zhen), soon(jiang), again(zaici)". Now, it can co-occur with the adverbs such as "just(jiu), very(hen), much(duo), again(zai), more(geng)". The deontic modal verbs such as "can(keyi), should(yao, yinggai, gai)" and "Meizhunr" constitute discontinuity co-occurrence. Also, at the same time, it could co-occur with the adverbs such as "just(jiu), still(hai), not(bu)". "Meizhunr" could co-occur with the dynamic modal verbs such as "may(keyi), can(neng), want(xiang, yao), would(hui)". Also, it co-occurs with the adverbs such as "still(hai), also(ye), not(bu), again(you), just(jiu), all(dou), actually(zhen), more(geng), but(dao), by accident(pengqiao), only(pian)" For example:

（15）这时便有好心同事告诉他, 何不到此地走走, 看似猎奇, 也没准儿会有全新的收获。At this time, a kind colleague told him why he would not take a walk here, which seemed like novelty, and perhaps something new might ("Meizhunr") be gained. (Tie Ning. "Story of Yellow Rice")

(16) 真是祖宗积德呀! 没准一家人都要给堂上列祖列宗多烧几柱 高香。It is the virtue of ancestors! Maybe ("Meizhunr") the whole family should burn a few more columns of incense for the ancestors. (Web corpus)

(17) 在华五年的从业经验告诉他, “那里面的一句话没准就能带 来一个行业的开放。” Five years of experience in China tells him, "the words may ("Meizhunr") bring about the opening of an industry." (Xinhua News Agency, February 2004)

The adverbs and modal verbs co-occurring with "Meizhunr" sometimes form continuous concurrence. Such combinations include " have to(ye dei), hai dei, zhen xiang, you yao, jiиyao, hai yao, really want to(pian yao), jiu keyi, ye keyi, hai keyi, jiu gai, ye gai, jiang hui, zhen hui, hai hui, ye hui, jiu hui, you can't keep it(ye hui baobuzhu), dou neng, dao neng, geng neng, jiu neng, you neng, hai neng, ye neng, pengqiao neng, jiu neng jizao, hui zaici, hui hen, neng jiang, hai zhen neng, jiu yue neng, will be also in the future(jianglai hai hui), will soon be in the future(henkuai jiuhui)" For example:

(18) 长栓悄声安慰众人: “我说也别太紧张了, 没准明天就会放 了我们呢, 虚惊一场吓着自己可不合算啊! ” Changshuan whispered to the people: "Don't be nervous, perhaps ("Meizhunr") they will release us tomorrow. A false alarm frightens ourselves is not worthwhile!" ("Qiao's Grand Courtyard")

（19）秀莲想了很久, 完了说: “我还是觉着, 再学下去也没用。 没准我也得嫁人，也得教个臭男人揍。” Xiulian thought for a long time, and then said, "I still feel that it is no use learning." Maybe ("Meizhunr") I have to marry someone, and be beaten up by a man. (Lao She. "Drumming Artist")

（20）他说这些不着急卖了，现在市场上小麦价格正上涨，没准留 着还能卖个更好的价钱。He said that there was no hurry to sell them, and now the price of wheat is rising in the market, and it may ("Meizhunr") still be able to sell at a better price. (People's Daily, 1998)

In conjunction with adverbs and modal verbs, we find that the present order of "Meizhunr" and modal verbs is "Meizhunr" > "Modal verbs". And the adverbs are flexible in their present positions. It can appear before and after the adverbs. The combination of adverbs and modal verbs is also flexible, and may appear before or after the modal verbs.

\section{Semantic Features of "MeIZHunR"}

"Meizhunr" is a subjective inference of the speaker to the uncertainty. The main semantic features are [+ speculative], [+ uncertainty], [+ true conclusion] (Luo Yaohua, Liu Yun. 2008: 44). To this kind of uncertainty, "Meizhunr" often contains the speaker's subjective positive speculation (Wang Qiuping, 2015: 27). "Meizhunr" may have the characteristic of "[+ irrealis]". It is the speaker's subjective inference about the content of expression. When "Meizhunr" and the adverb appear together, the subjective uncertainty of the speaker is strengthened. Along with the modal verbs, the uncertain semantic elements of "Meizhunr" increase the speaker's subjective judgment or attitude. And the whole sentence becomes more subjective. For example:

(21) 熟悉他的人都说, 这人的后门不敢走, 越找没准还得多加两 年。Those who know him well say that we can't ask for man's help. And the more we ask, the more he may ("Meizhunr") have to add two more years. (Selected Newspapers and Periodicals, 1994)

(22) 拿出对巴西队比赛的劲头和水准, 战平土耳其队是很有希望 的，打好了没准能爆个冷门。Taking out the strength and standard of the match against Brazil, Turkey is very promising. Maybe ("Meizhunr") it is the black horse. (Xinhua News Agency, June 2002)

In the example (21), "Meizhunr" expresses the speaker's presumption that "backdoor" may be counterproductive "for an additional two years", subjectively suggesting that the outcome of this uneventful event may be true. In example 
(22), "Meizhunr" conveys the subjective presumption that the speaker is not sure whether or not "Turkey" can be defeated.

If "Meizhunr" is used with negative semantics, the mood is more euphemistic. And the speaker interprets it from the listener's point of view, which reflects the intersubjectivity and the principle of politeness in daily conversation. For example:

（23）以下半场的形势走向来看, 假如比赛再多进行几分钟, 英格 兰队没准就要输掉比赛。Looking at the second of game, if the game goes on for a few more minutes, England may ("Meizhunr") lose the game. (Xinhua News Agency, June 2002)

(24) 如果不是棚架的缓冲, 没准他就摔痽榣了。If it wasn't for the buffering of the scaffolding, he might ("Meizhunr") have been paralysed. (Yu Hua. "Cry in the Rain")

In example (23), the expression of the negative meaning of "losing a game", the word "may" is used to soften the tone. And the listener does not feel stiff or abrupt, making the subjective evaluation seem implicit. In example (24), the use of word "might" makes this unpleasant hypothesis less abrupt. It is for this reason that the principle of cooperation in dialogue should take into account the feelings of the hearer, which is also the principle of politeness that should be followed in conversation. Because of the [speculative] semantic features of "Meizhunr", it is usually followed by declarative statement.

\section{CONCLUSION}

According to the syntactic features, "Meizhunr" can act as a syntactic component. And it is mainly as an adverbial, which can be distributed in the beginning, the middle, and the end of the sentence. The position is flexible. It belongs to the outside-proposition element and has the syntactic function of epistemic modal adverbs. It can be placed in front of the adverb, after the adverb or between the adverbs. It can be discontinuous with all types of modal verbs. Its syntactic position is higher than the modal verbs. It can be combined with adverbs and modal verbs, and its syntactic position is higher than that of modal verbs or general adverbs. The frequency of co-occurrence of "Meizhunr" and the epistemic modal verbs is the highest. The basic word order of "Meizhunr" and "Modal Verb" is "Meizhunr > Modal Verb". Semantic features of "Meizhunr" include [+ speculative], [+ uncertainty], and [+ irrealis]. "Meizhunr" expresses the speaker's subjective speculative about the content of the expression. When "Meizhunr" is used with negative semantics, the tone is more euphemistic. And it reflects the principle of politeness in dialogue.

\section{REFERENCES}

[1] Department of Chinese, Peking University, Language Class 1955 and 1957. Note of Function Words in Modern Chinese[Z], Commercial Press, 1982. 北京大学中文系 1955,1957 级语言班 1982 《现代汉 语虚词例释》, 商务印书馆。

[2] Li Xingjian, Xu Jialu. Modern Chinese Standard Dictionary[Z] (3rd Edition), Foreign Language Teaching and Research Press, 2014. 李行
健、许嘉璐 2014 《现代汉语规范词典（第 3 版）》, 外语教学 与研究出版社。

[3] Lu Jianming. Research on the Use of Adverbs[J], Language Research (2nd period), 1983. 陆俭明 1983 副词独用考察, 《语言研究》第 2 期。

[4] Luo Yaohua, Liu Yun. 2008 Judging the Subjectivity of Tone-like Adverbs[J], Linguistic Research (3rd period). 罗耀华、刘云 2008 揣 测类语气副词主观性与主观化, 《语言研究》第 3 期。

[5] Lv Shuxiang. Eight Hundred Words of Modern Chinese[Z] (Updated Edition), Commercial Press, 1999. 吕叔湘主编 1999 《现代汉语八 百词（增订本）》, 商务印书馆。

[6] Min Jiaji. Common Words Dictionary of Chinese Dialect[Z], Zhejiang Education Press. 闵家䩀等编 1991 《汉语方言常用词词 典》, 浙江教育出版社。

[7] Peng Lizhen. Study of Modern Chinese Modality[M], China Social Sciences Press, 2007. 彭利贞 2007 《现代汉语情态研究》，中国 社会科学出版社。

[8] Wang Qiuping. The Semantic Biases and Subjective Differences among "Meizhunr", "Buyiding", "Bujiande" and "Shuobuding"[J], Language and Translation (Chinese version) (No.4). 王秋萍 2015 “没准儿” “不一定” “不见得” 和 “说不定” 的语义倾向性和 主观性差异, 《语言与翻译(汉文版)》第 4 期。

[9] Wu Chunlan. Analysis of "Meizhunr" and "Mei Ge Zhunr"[J], Literature \& Literary (No. 21). 伍春兰 2009 析 “没准儿”与 “没 个准儿”，《语文学刊》第 21 期。

[10] Zhang Bin. Dictionary of Modern Chinese Function Words[Z], Commercial Press, 2001. 张斌 2001 《现代汉语虚词词典》, 商务 印书馆。

[11] Institute of Linguistics, Chinese Academy of Social Sciences. Modern Chinese Dictionary[Z] (7th Edition), Commercial Press, 2016. 中国 社会科学院语言研究所词典室 2016 《现代汉语词典（第 7 版）》，商务印书馆。 